\title{
The Epidemic Prevention Approach in the Honest Narrations: A Contemporary Jurisprudential Study
}

\author{
Nahidah J. Abdulhassan, College of Islamic Sciences, University of Karbala, Iraq, \\ nahida.j@uokerbala.edu.iq
}

Nada Suhail Abdul Husseini, Ministry of Education, Al-Karkh 2 Education Directorate, Iraq

*Corresponding Author

\begin{abstract}
This research deals with the curative prevention of the dangerous disease, Corona, and presents a brief presentation of the definition of the terms of the epidemic in Islamic jurisprudence and the glorious Sharia approach in preventing it. Then, it is concerned with then knowledge of the provisions regarding epidemics according to the noble narrations and hadiths and an overview of the epidemic of the Corona era from the beginning of its spread to the salvation of it in addition to the most important fatwas of Muslim scholars and religious references.
\end{abstract}

Keywords: Epidemic Prevention Approach; Corona Virus; Honest Narrations; and Contemporary Jurisprudence

Received: 04.12.2020 Accepted: 14.01.2021 $\quad$ Published: 01.02.2021

\section{INTRODUCTION}

There is no doubt that a person can protect his body from exposure to many diseases if he moves away from the sources of infection by following good health habits, by improving housing, clothing and food conditions, as well as by strengthening the human body's defense systems against diseases by taking care of his food in terms of quantity and quality, and by resorting to periodic checks in the state of health and disease among specialist doctors, and by applying specific prevention towards certain diseases or occupational factors such as vaccinations, choosing the appropriate environment at work and special protective clothing, the Messenger of Allah, may Allah's prayers be upon him and his family, said "Allah is good and loves good and cleanliness" (1). Religious teachings have urged the preservation of the public health of individuals and society, because it is one of the best blessings and the importance of prevention is evident in the diseases that afflict humans and medicine cannot cure them when they occur or to avoid their deformities and deformities.

Among these diseases are diseases caused by (viruses), as it is known that no antibiotic is currently available to fight deadly viruses and eliminate them, as is available for many germs. Therefore, most efforts are currently being made to prevent these viral diseases. Islam warns in the souls of the believers that they are satisfied with the decree of Allah and his destiny, and contentment with what comes to them, and patience for what has afflicted them, and calls on them to pray and seek forgiveness, repentance and prayer, just as Islam orders them to prevent and protect and to take the reasons for leaving and eliminating these epidemics. In view of the spread of infection with the emerging corona disease in the world, prevention is better than treatment, a saying that we have become accustomed to hearing from an early age even mechanical, such as accidents and others.

The noble Sunnah is full of examples in which the Messenger warns Muslims not to walk willingly to a place of sickness, and in it he warns the believers of the plague and advises them in the event that the disease falls on a land while they are in it not to leave it, and if it falls on a land while they are not present in it, do not land on it In this age, one can only see the extent of the similarity that may reach the point of coincidence between these prophetic commandments and what doctors advise in facing the Corona virus of the age.

This virus called Corona has spread in most countries of the world and has killed thousands of people, so they must be careful and raise collective awareness in surrounding this epidemic and eliminating it, Allah willing.

\section{Epidemic}

An epidemic is defined as a state of spread of a specific disease, where the number of cases of infection is greater than what is expected in a specific community, geographical area, season or period of time. This is according to the definition of the World Health Organization. The epidemic may occur in a confined 
geographical area or extend to several countries, and it may last for several days or weeks, and may continue for years. Epidemic is a term used to describe any problem that has gone out of control, and an epidemic is medically defined as the widespread spread of an infectious disease among a large number of people in one community or several societies within days or weeks. There is a difference between two important terms, which are epidemic and outbreak, and epidemiologists have promised that these two terms are identical, while the term epidemic describes a situation that includes a large area and is associated with a large crisis, while an outbreak expresses a disease spread in a specific area or areas smaller than the epidemic. A disease is considered an epidemic when the number of disease cases rises from what is usually expected in a particular region, and epidemics have posed a permanent threat to human health throughout history, despite the remarkable progress in preventing and treating infectious diseases, but epidemics still threaten the population with the emergence of new diseases and the return of some ancient diseases, and travel also contributes to the spread of infectious diseases.

\section{Related Words}

\section{Pandemic}

The plural name of pandemic is pandemics and pandemics afflicted by a pandemic are calamity, perdition, and a bad year. Pandemic can be scourge, dusty, barren. In the tongue of the Arabs, a pandemic is the great distress and calamity that sweeps away money from a year or sedition, and a pandemic is an epidemic that spreads among humans in a large area, such as a continent, for example, or it may expand to include all parts of the world. Pandemic is the terminology of the jurists: no fruit or part of it is gone from a heavenly pest .And that a pandemic is every pest that the human being has not made in it, such as wind, hail, locusts and thirst, according to Jaber that the Prophet spent in the pandemic, and the pandemic will be in the cold and locusts, basil and torrential and in the wind. Perhaps the connotation of the word came in the sense of staying in the place and staying there for a long time, and this necessitates a temporal stay as well, and this is what happened from the Corona order when it invaded the geographical place and its uncle, and it stayed long, and still is. It also came in the sense of eradication. A pandemic is a disease or weakness that lasts for a long time. The pest may be general, such as an epidemic, and it may be special, such as mute and madness.

\section{Plague}

Ibn Mandhur said that the plague is the general disease and the epidemic that spoil his air, his moods, and chilling and said the person that the injury plague, and stabbed the person he is transfixed, and the word plague came on the weight of appeal sense which is the original meaning, but it gives An indication close to it, indicating the death that afflicts a group of people, so it is common among them like an epidemic.

The plague is sores that come out in the body and are in the armpits, elbows, hands, fingers, and the rest of the body, and it has swelling and severe pain, and those sores come out with flame and what is around it is blackened or green or reddish-violet brownish, and with it heart palpitations and vomiting .The scholars differentiated between the epidemic and the plague, so they considered the plague as an epidemic and not the other way around, and Ibn al-Qayyim mentions that the issue between the epidemic and the plague is a general and specific issue. Every plague is an epidemic, not every plague, and likewise general diseases are more general than the plague. It is one of them. Any plague, one of the types of epidemics. And what Hebron mentioned on this subject, saying: The epidemic is the plague, which is also every general disease, she says: The people of Koura struck a severe epidemic and a land and an epidemic, if its disease abounds, if its diseases abound, as the plagues are often unknown to the source, while the source of the epidemic in general is known.

\section{Prevention and Treatment of the Epidemic}

Among the methodology (prevention is better than cure) contained in the noble narrations and its implications are evident in the verses of the Holy Quran and in the narrations on the authority of the Messenger and on the authority of the People of the House, in the Almighty saying: Benefactors), and others that lead to preserving the soul and body and not falling into perdition. The Islamic Sharia promised to "cure when diseases occur, and to prevent every harmful person, whether human or otherwise, and to guard against expectations until he presents the kit, and so is the rest of what he does to live in this house to ward off evil and bring interests" (1).

And that the approach (prevention is better than cure), as we mentioned, is the way and the creed followed with faith in the wisdom and power of Allah, so despair from the mercy of Allah, terror, or panic is not valid for what befalls him of a disease or an epidemic, because his mercy is wide, and contentment with the judgment and destiny of Allah is true. He died from the epidemic, and from that 
what was mentioned in Sahih Muslim, Anas bin Malik said the Messenger of Allah said "The plague is a testimony for every Muslim". It is necessary to avoid the spread of these epidemics and not to transmit them to people if the patient himself or his clinic is by healthy people, and they mentioned that the benefit of the narrations in this regard is the following forbidding the riding of deceit and risking the soul and the excursion because it seems that most of the land and environment hardly spares its owner from the epidemic in it if He went down with it and forbade this phenomenon, because the periods and pains are hidden. Malik narrated in his Muwattah that the Messenger of Allah said there is no infection, no important, no zero, and the nurse does not go to the sanatorium, and let him analyze the sanatorium wherever he wants, so they said "Oh Messenger of Allah, and what is that?" The Messenger of Allah said "It is harm". On the authority of Imam Musa bin Ja far "The Imam looked one day at a woman calling for her teddy bear to be cured of the scabies disease, and he said to her "would you add a little bit of tar to your supplication". With the supplication, he commanded her, peace be upon him, to apply tar on the skin of the animal to heal her bear from Scabies". And among the Sunnahs of the Prophets and Guardians, peace be upon them, is to resort to medicine and medicine, for this is the Prophet of Allah Moses, peace be upon him, Allah commanded him to go to the doctor when he fell ill.

Then the Almighty inspired him to go to the doctor when he fell ill, peace be upon him and the Almighty said to him "I made my servant's livelihood in the hands of my servants", meaning that if you You want Allah to bless you with healing, so you have to resort to his natural causes, even though Moses, peace be upon him, is the speaker of Allah and can pray and ask Him to heal by the miracle. And this is the Commander of the Faithful, peace be upon him, that our good imam, peace be upon him, came to him with Kufa healers, including Atheer Al-Kufi, when Ibn Muljem struck him on the mother of his head with a poisoned sword .... Imamate scholars are unanimous on the argument of the doctor's clever confidence saying, and on the authority of referring to the doctors as experts from the door of authenticity. The words of the people of experience in what they are experts. Many stories have been received in this area.

\section{The Jurisprudential Provisions of the Epidemic}

There is no doubt that Islamic law has not neglected the treatment of diseases that afflict humans, especially epidemics and plagues, and several rulings have been mentioned in this regard, as some of the scholars mentioned which is deduced from the words of the majority of jurists and the reports of their investigators that the disease of death or plague is the dreaded disease that is related to death even if death was not caused by him. Ibn al-Qayyim cited a sentence of wisdom related to the wisdom of prohibiting entry into a land with an epidemic, and he mentioned that the Prophet gathered the nation in his prohibition on entering the land he is in (2).

And in preventing entry to the land that has occurred in several things, including, one, avoiding harmful causes, and distance from them; second, the introduction of wellness, which is the material of the pension and return; the third, that they not breathe air that has rotten and spoiled and become sick; fourth, that they do not go near the sick who have become ill by that, so that it will happen to them next to them of the same type of diseases; fifth, to protect souls from birds and infection, they are affected by them, for the bird the one who flies with it, and in the sentence, in the prohibition on entering his land, is the order of caution and diet, and the prohibition of exposure to causes of damage. In the prohibition on fleeing from it, the order to trust, surrender, and delegate, the first: discipline and education, and the second: delegation and surrender.

Among the mental judgments discussed in the science of the fundamentals of the jurisprudence of Sharia in the study of the independent rationalities are the rational judgments that the holy street passes, and among these mental autonomies is the necessity of paying the expected possible harm, so how about the semi-cut damage by its occurrence with the increase in the spread of the Corona epidemic in the world and the methods of its rapid transmission by mixing, shaking hands and neighboring touch and meet.

It was mentioned in the biography of the Prophet that he commanded Muadh ibn Jabal and the group of the Companions, if the epidemic spreads so that no one who entered it will leave it, indicating from him the need for health isolation. Also in the Noble Sunnah there is evidence of quarantine. While the scholar Sheikh Muhammad Baqir al-Majlisi transmitted it in his book (Seas of Lights) and narrated with his chain of transmission from Imam Abu Abdullah Jaafar bin Muhammad al-Sadiq on the authority of his fathers (3).

The Messenger of Allah said "Less than looking at people of calamity and do not interfere with them, and if you pass by them walk faster, so what happened to them will not happen to you" (4). In a reference from the Prophet to the necessity of avoiding those afflicted with epidemics and what is included in the conversation in the general population of those infected with infection that one of the axioms of which is not to flock to places of gathering, and history has mentioned to us the occurrence of 
epidemics, such as malaria, typhoid, cholera, meningitis, tuberculosis, viral hepatitis and other infectious diseases. Transmitting the disease to other Muslims, dhimmis and treaties is not permissible according to the consensus of the jurists, because it is forbidden to harm them definitely, and deliberate violators are punished with what the legitimate ruler deems good, and it is forbidden to transfer germs to others even if they are not really a disease for him. According to the rule of lawfulness, it can be said that this is forbidden according to Sharia, and likewise by the prophet's statement "no harm, no foul", so harm is absolutely forbidden, except as the legal evidence indicates that it is permissible, such as slaughtering an animal and making use of it (5).

\section{Epidemic of the Era "Corona"}

The first infection with the virus appeared in $1937 \mathrm{AD}$, and infections increased in birds and animals, which led to the death of hundreds of them, then symptoms, appeared on other types, such as cattle and cows, and the first case was recorded in humans, and the first infection was in 2012. These are Corona viruses are a large group of viruses that can infect animals and humans alike, as they cause respiratory diseases, whether they are mild such as the common cold or severe such as pneumonia. Animal corona viruses rarely infect humans and then spread among them.

Among them is SARS (severe acute respiratory syndrome), which spread between the years of 2002-2003, and which was an example of the Corona virus that was transmitted from animals to humans. And another, newer, prominent strain of the Coronavirus called MERS (Middle East Respiratory Syndrome) appeared in the Middle East in 2012, and scientists say it was initially transmitted from a camel to a human. These strains of this virus produce very dangerous diseases, and have their own environment: they take the shape of a crown when viewed with an electron microscope. It means in Latin (corona), meaning crown and it has the same meaning in Spanish and English (6).

Corona viruses are so named because of their image under a microscope, which looks like a crown. Dr. Watson says: The name given to the virus is not easy to use, and the media and the public have resorted to using other names for the virus, and she said in another statement to her "We saw that some names of diseases provoked violent reactions in some religious and ethnic groups, and created unjustified barriers in travel, and trade, and led to the killing of some animals that feed on their meat." Today, it has become an epidemic of the age, with the news about the global epidemic that is increasing in spread day after day, called the Corona virus, and this epidemic has caused the death of a large number of people and some others affected cases of fear and panic, especially in the countries in which it spread.

Many infections with this virus 2019 AD were discovered in a number of global countries, so groups specialized in public health, such as the World Health Organization and the Centers for Disease Control and Prevention in the United States monitored the matter and published updates on their websites. And the World Health Organization declared this disease (a global pandemic) in March 2020 (7).

These groups also issued recommendations on preventing and treating the disease.On this date, January 31,2020 , nearly 75,775 thousand cases were confirmed, including the entire provinces of China, including Wuhan. Among the first 41 people confirmed to have the infection, two-thirds of them have been found to be linked to the Wuhan seafood wholesale market that also sells live animals. The first confirmed death from infection with the virus occurred on January 9 and since then 3,015,000 people have been confirmed dead. Studies estimate that more people may be infected, but have not detected them medically. The first spread of the virus outside China was in Vietnam from a father to his son, not including members of the same family, then it moved to Iran starting from the holy Qom, then events unfolded in Germany on January 22, when a German man fell ill from a visiting Chinese businessman at a meeting In the German state of Bavaria (8).

A number of countries' governments issued warnings against travel to Wuhan and Hubei provinces. Airports and train stations conducted a series of checks that include temperature or quarantine checks, health announcements as well as a summary of information on billboards in order to identify carriers of the virus, Chinese scientists were able to isolate and determine the genetic sequence of the virus" (9). They made it available so quickly that others could independently develop polymerase chain reaction (PCR) tests to detect the disease, and announced that the 2019-nCoV genome sequence matches between 75 and 80 percent of the SARS sequence, and more than 85 percent of coronaviruses are transmitted from bats. But it is not clear if this virus is from the same deadly chain of SARS. And in the lean days that the epidemic has spread in the world, "Corona", we must adhere to Islamic law and follow its approach to preventing it that was mentioned in the noble hadiths, to calm souls and calm them from the fear and panic that may befall them (10). 
The Sharia took care of the human being and preserved him and his health in particular, according to what was mentioned by the Great Messenger, and the sayings of the people of the house and the leading imams.

\section{Islamic Scholars Fatwas about Corona Epidemic}

Global countries have taken proactive and preventive measures and scholars issued fatwas related to this matter to limit the spread of this epidemic, and through the fatwa, the official religious authorities in some countries have settled the issues raised regarding the provisions for performing collective worship in light of the spread of "Covid-19", as well as the ruling legal rumors spreaders and those who do not comply with the instructions of the competent health authorities. Specialized doctors have confirmed that this epidemic is spreading in gatherings, so they obligated people to refrain from it (11).

So the authorities from all sects responded to prevent such gatherings with the fatwa, holding those who know that they are infected with the disease responsible for treating those who cause the spread of the epidemic to him and obligating him to start deliberate or semi-intentional killing if he caused the killing of those to whom the epidemic was spread intentionally or almost intentionally, if he was unaware that he was infected and mixed with others in the jurisprudential detail in the fatwas, so the Shiite jurists forbade people from Friday and congregational prayers, even in the shrines of the people of the house and visiting them. With the increasing spread of the Corona epidemic in the world, the methods of its rapid transmission through contact, handshake, close proximity, contact and others were also pervaded (12).

It was mentioned in the biography of the prophet that he commanded Muadh ibn Jabal and the group of the companions, if the epidemic spreads in the Levant, that no one who entered it, may Allah bless him and his family, leave it, indicating the need for health isolation, as well as what was mentioned in the noble Sunnah indicating quarantine As for the scholar Sheikh Muhammad Baqir al-Majlisi, he narrated with his chain of narration on the authority of Imam Abu Abdullah Jaafar bin Muhammad alSadiq, on the authority of his father said the Messenger of Allah, said "be less looking at the people of calamity and do not interfere with them. You passed by them and hurry to walk, so what happened to them will not happen to you", referring to the necessity of avoiding the afflicted, and what is included in the conversation in general are those infected with the epidemic, which one of the axioms of which is not to flock to places of gathering (13). On the other hand, the Supreme Authority in Iraq, Mr. Ali Al-Sistani, issued a new fatwa related to the work of employees in the health sector, considering treating those infected with the new Coronavirus as a competent duty (14).

Treating and caring for the sick and carrying out their affairs is a sufficient duty, and he added in a statement published on his official website that the work of these employees is close to the importance of stationing heroic fighters in the trenches in defense of the country and its people. It is said that on Judgment Day, Mr. Sistani called on the authorities to provide all necessary supplies to protect them from the risks of contracting the disease" (15). He also issued a fatwa not to have contact with those infected with the Coronavirus without those who are infected, and considered that the injured person must pay money if he causes injury to another person, regardless of religion and sect, and also called for the commitment of travelers.

Those coming from other countries to home reservations, review doctors and follow the instructions of the authorities. He considered that the Sharia does not excuse those who do not take preventive measures and become infected with the virus, and indicated that there is no objection to spending from the zakat money on buying tools to protect against infection such as gloves, masks and sterilizers, according to Sharia controls. He considered that whoever carries the virus and travels with knowledge of his infection is a "willful killer", and he also announced the cessation of holding group prayers in mosques and commitment to preventing gatherings, and he also issued a fatwa, saying that there is no objection to burying the bodies of the dead with the Corona virus in public cemeteries, stressing the prohibition of burning the bodies of the victims (16).

The Iraqi authorities have taken a number of decisions to control the spread of the epidemic, including imposing a curfew in several cities, banning religious visits and public gatherings, closing schools and universities, cutting working hours in government institutions by half, in addition to reducing the opening of shops to only three hours per day. As for the Ifta Authority of the Kuwaiti Ministry of Endowments, it issued a decision to suspend the Friday sermon and prayer until further notice as a precautionary measure for fear of the spread of the Corona virus in the country. The Emirates Fatwa Council issued a fatwa on the provisions for performing collective acts of worship, given the requirements of the public interest in dealing with the emerging corona virus and the need for cooperation of all authorities in the country to address this disease and considering the obligation of obedience to the guardian of Muslims in all instructions he orders (17). 
The council said in its fatwa that it is imperative for all groups and segments of society to adhere fully to all health and regulatory instructions issued by the competent authorities in the state, in addition to taking all necessary measures to prevent the transmission and spread of the disease, and it is not permissible to violate them in any case. He stressed that "it is forbidden according to Sharia for anyone who has contracted this disease or is suspected of being infected with it, to be in public places, or to go to the mosque to attend group prayers, Friday or Eid prayers, and he must take all necessary precautions by entering quarantine" (18). The council affirmed that "all parties must legitimately cooperate with the competent authorities and provide them with the necessary support, each in its own right, to limit the spread of the disease and eliminate it, and to prevent the spread of rumors related to it by only obtaining official information from the competent authorities". For its part, the Saudi Council of Senior Scholars has issued a fatwa ruling that it is forbidden to pray for a person with Coronavirus in congregation, as well as for him to attend Friday prayers.

The commission indicated that those who have decided to be competent in the procedures of isolation must abide by that, and leave witnesses to group and Friday prayers and pray the prayers in his home or place of isolation. The commission recommended that everyone adhere to the instructions, directives and regulations issued by the competent authorities, and the Saudi authorities announced, at an earlier time, the suspension of Umrah and I'tikaaf at the Two Holy Mosques and visiting the well of Zamzam for fear of an outbreak of the Corona virus (19).

In Egypt, the Grand Mufti, Dr. Shawqi Allam, called on the Egyptian people to remain steadfast and calm in the face of the Corona virus, to abide by the official state statements, and not to be drawn to the rumors and lies launched by malicious people to spread terror and destabilize security (20). That the Ministry of Health and the competent authorities announce, calling for adherence to the instructions of our true religion of constant concern for purity and cleanliness, and the Mufti warned against exploiting the crisis to exercise monopoly over food, medical or other commodities, and to promote medical goods or preparations that are not approved by the competent authorities and that such practices Taboo and ugly. Dr. Khaled Omran, Secretary of the Fatwa at the Egyptian Dar Al Ifta, also mentions "ellers and merchants who take advantage of the crisis of the spread of the Coronavirus to block goods spoil the land (and Allah does not like spoilers), warning that they are a cause of Allah's wrath on the people and the country" (21).

\section{CONCLUSIONS}

In the conclusion of this research, we summarize in it matters from the prevention approach is better than treatment, as it limits epidemics, including the Corona age epidemic, because if a person is affected by something of an infectious disease; He should avoid mixing with others. In order to preserve their health, to protect their safety, and to ward off harm on their behalf, this includes all public places, including mosques, and what one preserves the safety of others. We have to be keen on those Islamic directives in the noble narrations, whose meanings and connotations we are aware of achieving the public interest, and we must cooperate with them and not contradict them in achieving this interest, and following the teachings of the Islamic religion in this field, and preserving the health of citizens and residents from any harm, Allah willing. As for the results, we reached the following:

1. The role and effect of cleanliness in the prevention of epidemics and other diseases, and purity and cleanliness in Islam are of great importance. Indeed, if a person maintains his healthy food and a proper diet, he will protect himself from many diseases.

2. Quarantine in Islam, which the Messenger, may Allah's prayers and peace be upon him, ordered, to quarantine those infected with epidemics that transmit the disease to other healthy people, so that the infection does not spread to others, so that the epidemic spreads among people.

3. Prevention of epidemics and diseases that the person adhere to and follow the instructions and instructions issued by the competent medical authorities from doctors, specialists and relevant institutions, experience and knowledge in the means that prevent the transmission of infection and help in the prevention and treatment of the risk of epidemics and diseases.

4. Seeking treatment for diseases and epidemics, and reviewing hospitals and medical and health centers to diagnose illness and seek the help of treatment and medicines that are recommended and prescribed by doctors to the patient.

5. In light of the current health crisis associated with the spread of (Corona virus) in the world that recorded cases of infection with it, we note the medical and preventive measures taken by government authorities and individuals, in order to contain the crisis to prevent it from turning into an epidemic that threatens everyone, correct measures that express deep awareness With the size of the danger they face to humanity, and the application of precautionary measures, such as 
caring for good food that strengthens the immune system, washing hands well, wearing the appropriate masks, etc., and countries must take measures, precautions and directions to reduce this disease.

6. By presenting the terms of the epidemic and related terms, we note that the term pandemic is not commensurate with the Corona epidemic because a number of narratives contradict in its linguistic and idiomatic meaning, as well as the plague.

\section{REFERENCES}

Al-Shafi'i Abu Abdullah Muhammad bin Idris bin al-Abbas bin Othman bin Shafi'i bin Abdul Muttalib bin Abd Manaf al-Muttalibi al-Qurashi al-Makki. Al-Uom. Dar al-Maarifa: Beirut. 1410 AH-1990AD.

Abu Omar Yusuf bin Abdullah bin Muhammad bin Abd al-Barr bin Asim al-Nimri al-Qurtubi. Recitation. Edited by Salem Muhammad Atta, Muhammad Ali Moawad. Dar al-Kutub al-Ilmiyya: Beirut. 1421$2000 \mathrm{AD}$.

Muhammad Baqir Majlisi. Sailor Al-Anwar Al-Jami` of Durrar News of the Immaculate Imams. Wafa Foundation: Beirut.

Abu Omar Yusuf bin Abdullah bin Muhammad bin Abdul Barr bin Asim al-Nimri al-Qurtubi. Introduction to the Meanings and Chains of the Muwatta. Ministry of All Endowments and Islamic Affairs: Morocco. $1387 \mathrm{H}$.

Abu Mansour Al-Azhari. Language Refinement. Dar revival of Arab heritage, Beirut.

Muhammad bin Abi Bakr bin Ayyub bin Saad Shams al-Din Ibn Qayyim. The Return Increased in the Guidance of the Best of Servants. The Message Foundation, Beirut, Al-Manar Library.

Muhammad bin Isa bin Surah bin Musa bin Dhahak, Tirmidhi. Sunan al-Tirmidhi. Islamic West House Beirut 1998.

Muhammad bin Ismail Abu Abdullah al-Bukhari al-Jaafi. Sahih Bukhari. House of the lifeboat $1422 \mathrm{AH}$.

Muhammad bin Abi Bakr bin Ayoub bin Saad Shams al-Din Ibn Qayyim. Prophetic Medicine. Dar Al-Hilal: Beirut.

Abu Muhammad Mahmoud Al-Gheitabi. Mayor of Continental. Explanation of Sahih Al-Bukhari. Dar revival of Arab heritage, Beirut.

Muhammad Asif al-Mohseni. Jurisprudence and Medical Issues. Yaran.

Shirazi Turquoise. Dictionary of Muheet. Al Hussainia Press: Egypt 1330 A.H.

Abu Jaafar Muhammad bin Ya'qub bin Ishaq. The Origins of Al Kafi Al Kulayni. Haidary Press. Publishing House of Islamic Books. Tehran. $1363 \mathrm{AH}$.

Jamal al-Din Muhammad bin Makram. Lisan Al Arab Ibn Manzour. Library science, Beirut. 1320.

Ibrahim Mustafa. The Intermediate Dictionary. The Academy of the Arabic Language, Dar Al Da'wah: Cairo.

El-Sherbiny, Muhammad. The Needy Singer. House revived Arab heritage. Beirut, 1377 A.H.

Abu Abdullah bin Asad Al-Shaibani. Musnad of Imam Ahmed bin Hanbal. The Resala Foundation. 1421 AH $-2001 \mathrm{AD}$

Abu Muhammad Muwaffaq al-Din al-Maqdisi, then al-Dimashqi al-Hanbali. The Singer. Cairo Library.

Abu Ishaq Ibrahim Al-Maliki. Approvals in the Fundamentals of Sharia al-Shatibi. Library science, Beirut.

Malik bin Anas. Al-Muwatta. Islamic West House.

Al-Hur Al-Amili, Muhammad bin Al-Hassan. The Means of the Shiites to Collect Matters of Sharia. Aal alBayt (peace be upon him) Foundation for the Revival of Heritage, Mehr Press, Qom, 2nd Edition, $1414 \mathrm{AH}$.

D. S. Q. Al-Yasiri and A. J. Obaid, "A New Approach for Object Detection, Recognition and Retrieving in Painting Images," Journal of Advance Research in Dynamic and Control System, vol. 10, no. 2, pp. 2345-2359, 2018. 